\title{
Freire-väitös on kulttuuriteko
}

Aino Hannula (2000) Tiedostaminen ja muutos Paulo Freiren ajattelussa. Systeemaattinen analyysi sorrettujen pedagogiikasta. Helsingin yliopiston kasvatustieteen laitoksen tutkimuksia 167.

\section{Kiinnostus Paulo Freiren} elämäntyötä kohtaan on lisääntynyt myös Suomessa. Tosin se edelleenkin jää yksittäisten henkilöiden varaan, eikä ole osana yleistä koulua ja didaktiikkaa koskevaa keskustelua. Näin toteaa Aino Hannula väitöskirjassaan "Tiedostaminen ja muutos Paulo Freiren ajattelussa. Systemaattinen analyysi Sorrettujen pedagogiikasta”. Hannulan väitös on kasvatuksen kulttuuriteko. Sinänsä aiheena tiedostamisen problematiikka ei ole kovinkaan omaperäinen eikä uusia uria aukova, mutta Hannulan avaama freireläinen näkökulma tiedostamiseen ja muutokseen antaa kasvatukselle uusia eväitä. Erityinen merkitys Hannulan kirjalla on Freiren merkittävimmästä kirjasta "Pedagogy of the Oppressed" tehdyssä systemaattisessa analyysissä.

\section{Hannulan teos tarjoaa}

Freirestä kiinnostuneelle mahdollisuuden hänen kasvatusajattelunsa ydinasioiden ymmärtämiseen. Freiren ajattelun moninaiset elementit ovat aiheuttaneet hänestä muutoin kiinnostuneille ongelmia "alkuperäisen" Freiren tavoittamisessa. Kaikessa teorian sovelluksessahan on yleensä kyseessä teorian tulkinta, mutta Freiren kohdalla sitä on tehtävä syvällisemmin. Se johtuu osaltaan häntä koskevan suomenkielisen kirjallisuuden vähäisyydestä. Nyt Hannula täyttää väitöksellään yhtä aukkoa, mutta se ei poista Freiren keskeisimpien kirjojen suomentamistarvetta. Hannula tuo työnsä "syväsukelluksen" kautta esiin nyt yhden tulkinnan Freirestä. Tulkinnan ohella avautuvat Freiren käyttämien käsitteiden tiedostaminen, muutos, praksis ja dialogi sekä opetukseen liittyvien uudempien käsitteiden sisältö.

\section{Freiren käytännön}

sovellusten ongelmana on ollut vaara ajautua Hannulan esiintuomaan pintapuoliseen toteutukseen. Tälle on ilmeisenä osasyynä Freiren pedagogiikan vaikeus ja hänen teoriansa monipolvisuus sekä eklektisyys ja kielen abstraktisuus, minkä vuoksi kasvattajalta itseltäänkin vaaditaan syvällistä tiedostavuutta. Kun luokkahuoneopetus ja kasvatus yleensäkin ovat muuntuneet vuorovaikutuksellisemmaksi, on saattanut tulla tunne siitä, että Freiren tarkoitus on näin jo toteutunut. Tämän harhan torjumiseksi on tarpeen tuntea todellisia Paulo Freiren tarkoituksia. Hannulan kirja selkiyttääkin Freiren ajattelun perustan. Tosin edelleenkin käytännön kiireittensä parissa pakertava kasvatuksen ammattilainen tarvitsisi työlleen "kasvattajan kansanpainoksen". Hannula tuottaa käytännön toiminnalle pohjaa antavat kolme toiminnallista mallia. Nämä mallit ovat kasvatuksen sisällön organisoi- mista kuvaava temaattinen malli, oppijan oppimistyöskentelyä esittävä praksiksen malli ja opintopiirin toimintaa kuvaava dialogisen oppimisen malli. Malleja ei ole kuitenkaan tuotettu suoraan opetukseen sovellettavaksi, vaan tutkimuksen ja kasvatuksen suunnittelun työkaluiksi. Mallit ovatkin käytännön toimijalle arvokkaita työkaluja, kunhan ne otetaan kentällä käyttöön.

\section{Ongelmana käytännön}

kasvattajalla on se, miten Hannulan erinomainen systemaattinen analyysi avautuu ja ehtiikö hän purkaa itselleen mallien ja kuvioiden muotoutumisen perustat, jotka Hannula on kirjassaan esitellyt. Kuviot ovat yleensäkin erinomainen asian tiivistäjä ja selkiyttäjä, mutta niissä piilee myös omat vaaransa. Pelkästään niiden pohjalta toimiminen saattaa johtaa Freiren pedagogiikan tekniseen pintapuoliseen sovellukseen, jolloin Freiren alkuperäiset tarkoitukset jäävät täyttymättä. Käytännön toimijalle voineekin esittää suosituksen siitä, että on syytä lukea kunkin mallin muotoutumisen perusta.

\section{Hannulan teos avaa} systemaattisen analyysin kautta lukijalle Freiren vapautuksen pedagogisen ajattelun. Tutkimusote on hermeneuttinen, joka tuo lukijalle Aino Hannulan löytämän ja hänen ymmärryksensä mukaisen Paulo Freiren. Lukijalla on koko ajan kuva siitä, milloin puhuu Freiren ääni ja milloin on kyseessä tutkijan ääni ja hänen 
tulkintansa. Tässä mielessä Freirestä kiinnostuneelle kirjan lukeminen on miellyttävä kokemus, jolta pohjalta voi sitten tehdä omakohtaisia oivalluksia freireläisyydestä.

Freiren harrastajille on syntynyt kullekin tekemiensä tul-

kintojen kautta "oma Freirensä”, joka muuttuu sovellusten tuottajalla tilannekohtaisesti.

Kun nyt avautuu mahdollisuus tutkailla alkuperäisintä Paulo Freireä, se herättää lukijalle kysymyksiäkin. Yksi tällainen on esimerkiksi se, onko vastausta yhteen Freireen kohdistuneeseen kritiikkiin hänen ajattelunsa paikoittaisesta ristiriitaisuudesta? Tässä onkin huomattava muuttuva Freire, sillä hänen myöhemmissä töissään on varhaisempiin teoksiin nähden uudenlaisia elementtejä. Aino Hannula toteaakin Freiren ymmärtämisestä sen, että Freire liittää kasvatusajattelunsa kehittymiseen koko elämänkokemuksensa. Siksi hänen pedagogiikkansa soveltajan on tunnettava Freiren elämänhistorian vaiheita sisältöineen ja tätäkin tarvetta Aino Hannulan kirja täyttää.

\section{Muuttuvan Freiren}

löytämiseksi voisi nyt olla arvokasta analysoida hänen näkemystensä kehitystä myöhempien teosten analyysillä. Esimerkiksi "hiljaisuuden kulttuurin" käsitteen Freire on muodostanut kriittisellä analyysillä sosiaalisesta todellisuudesta ja sen ymmärtämisestä sekä muuttumisesta. Freire itse elämässään osoittaa todellisuuden analysointikykyään, kun hän laajentaa myöhemmin näkemyksiään hyvinvointimaailmaakin koskeviksi. Freire osoittautuu näkemystensä laajentumisen ja muut- tumisen kautta "marxinsa" lukeneeksi, sillä onhan huomattava ero nuoren Marxin ja meille enemmän välittyneen "varsinaisen" Marxin välillä. Freiren ajattelussa on kaiken aikaa hänen koko elämänkokemuksensa läsnä. Hannulan työn kohteena on Freiren varhaisempi tuotanto, mutta hän on onnistuneesti analyysissään ottanut huomioon koko elämänhistorian. Näin syntyy vaikutelmaa siitä, että tässä käyvät keskustelua Paulo Freiren kirjoitukset "sorrettujen pedagogiikasta" ja Freiren elämä kaikkine vaiheineen ja välittävänä toimijana on tutkija tekemässä analyysiä "keskustelusta".

\section{Hannula tiivistää Paulo}

Freiren pedagogiikan infrastruktuurin marxilaisuuteen ja Hegelin dialektiikkaan sekä pitää sen sydämenä kristillistä ontologiaa. Freiren kristillisyys tulee Hannulan tutkimuksessa varsin hyvin käsitellyksi. Jos Freiren pedagogiikan sydämenä olevaa vapautuksen teologista osuutta olisi laajennettu, niin siitä olisikin syntynyt aivan oma kokonaisuutensa. Tämä jo sinällään osoittaa Freiren käsittelyn vaikeutta. Hänen ajattelunsa analyysit saattavat fragmentoitua, ja pirstaloituneena kokonaisuuden hahmottaminen epäonnistuu. Hannula on onnistunut välttämään tämän ansan.

\section{Aino Hannulan johto-} päätösten kanssa on vaikea olla erimieltä eikä siihen ole tarvettakaan, sillä siinä määrin antoisa työ on kyseessä. Ehkä joitakin tulkintoja voisi miettiä syvällisemmin lähinnä Freiren henkilöhistorian ja hänen ajattelunsa tavoitteiston toteutumisen kannalta.
Tällainen on mielestäni se, onko Freiren lähtökohtana kasvatuksessa ongelmakeskeisyys vaiko ongelmalähtöisyys? Tämän tekstin kirjoittajakin on puhunut Hannulan tavoin ongelmakeskeisyydestä, mutta jos alkaa pohtia koko prosessia, saattaa ollakin parempi puhua ongelmalähtöisyydestä. Tällöin olisikin kyseessä oppijan elämässä esiintyvä ongelma, jota lähdetään oppimisessa tiedostamisen myötä poistamaan tai ainakin vähentämään. Näin ei jäädäkään pähkimään enää itse ongelman ympärille "tuleen makaamaan", vaan siitä lähdetään liikkeelle. Kun katsoo esimerkiksi Freiren brasilialaisten maanviljelijöiden opettamisen kuvasarjaa tai Amatsonasin kautsun kerääjien opetustapahtumaa, niin siinä tiedostetaan sortavat rakenteet ja lähdetään niistä ulos.

\section{Ongelmalähtöisyyden} tunne syntyy Hannulankin teoksen pohjalta, kun hän tiivistää yksilöllisen tiedostamisen sosiaalisen muutoksen edellytyksiä. Näitä ovat todellisuuden tunteminen, sanan muuttavan voiman ymmärtäminen ja oman ihmisyyden sekä vapauden kohtaaminen. Muutoksen edellytykset perustuvat tietoiseen todellisuutta ja itseä koskevien käsitysten muuttamiseen sekä dialogikyvyn kehittymiseen. Näin sorretut löytävät "äänen hiljaisuudelle" ja voivat liittyä itsenäisinä subjekteina yhteisen kulttuurisen maailman luomiseen. Näin on kriittisen reflektion kautta löytynyt uusia eväitä ongelmien ratkaisemiseksi.

\section{Aino Hannulan kirjan} esipuhe antaa suomalaiselle 
Paulo Freirestä kiinnostuneelle rohkaisua jatkaa häneen tutustumista ja sovellusten etsintää. Mittava nimilista osoittaa, että Freirellä on kasvatuksen kentälle sanottavaa. Suomalainen elämänmuoto arvostaa subjektikansalaisuutta ja tähän liittyvänä freireläinen emansipatorisuutta vahvistava ja muutosten aikaansaamista korostava ajattelu iskee ajan hermoon. Paulo Freiren ajattelu vastaa ajan tarpeisiin erityisesti tämän päivän syrjäytymiskehityksen ongelmien lievittämisessä. Freiren tarkoittama "hiljaisuuden kulttuuri" on keskuudessamme myös Suomessa. Hannulan tutkimuksen sanoma on tulkittavissa niin, että vaikka Freire puhuu sorrettujen pedagogiikasta, niin sitä voi pitää kaikkien ihmisten pedagogiikkana. Se on toisaalta kritiikin ja samalla toivon pedagogiikkaa.

Aino Hannulan kulttuuritekoa suomalaiselle kasvatukselle on Freiren ajattelun rakentumisen analyysi. Toivottavasti kasvattajille syntyy uskallusta toteuttaa freireläisyyttä omassa työssään siitäkin huolimatta, että ensi kommentti kollegoilta saattaa olla kysymys, kuinka se nyt kolmannessa maailmassa kehitettynä soveltuu suomalaiseen elämään? Freiren itsensä lähtökohta on ollut tilanne- ja ympäristökonteksti, jolloin tietynlaisessa kontekstissa toteutetaan omanlaisensa sovellus. Näin Freiren ystävyyttä ei riko se, että toteuttaa omanlaisensa freireläisen tapahtuman, kunhan muistaa pitää kiinni praksiksen ja teorian yhteydestä. Olisiko tämä seikka suomalaisilta kasvattajilta ajoittain jäänyt ymmärtämättä ja sorrutaanko turhan usein helppoihin teknisiin toteutuksiin?

\section{Hannulan teoksen luku}

"Freire kasvatusajattelijana" osoittaa Freiren merkitystä meikäläisten arvostamien kasvattajien Knowlesin, Mezirovin ja Giroux' in rinnalla. Tuntuukin merkilliseltä, kun Freire usein unohtuu huomattavia teoreetikkoja lueteltaessa. Sinänsä kyseinen luku on Hannulan teoksen kokonaisuudessa hieman irrallinen. Käytännön kasvattajalle luku sen sijaan on hyödyllinen. Suomalaiselle kasvattajalle hyödyllinen sanoma on Paulo Freireltä myös se, että kasvattajan pitää tuntea oppijaryhmänsä maailmaa. Hannulan kirja henkii Paulo Freiren persoonallisuuden olennaista piirrettä, jonka voisi tiivistää sanoihin "Hän eli opetuksensa mukaisesti". Paulo Freire omankin epitafinsa sanomassa painotti itsestään sitä, mitä hänen ystävänsäkin tuovat esiin: Freiren jättämä perintö on rakkauden sanomaa. Eiköhän nykyisessä suomalaisessa polarisoituvassa yhteiskunnassa tätä tarvita ja Freiren opetus voisi olla yksi mahdollisuus kamppailussa syrjäytymistä ja yhteiskunnallista apatiaa vastaan.

\section{Paulo Freiren tuotantoa} on luettava hitaasti ja antaumuksella. Tietyllä tavalla sama pätee Hannulan teokseen. Teos avaa paljon uutta jonkin verran Freireä tuntevallekin. Se tuo eteen yhden tulkinnan ja ymmärryksen Freirestä. Kun kyseessä on systemaattinen analyysi Sorrettujen pedagogiikasta, se ei yritäkään tuottaa valmiita sovellusmalleja. Niiden rakentaminen Hannulan teoksen pohjalta on mah- dollista. Teos painottuu tiedostamisen ohella muutokseen, jossa on sisällä transformaation ainekset. Ehkä yksi keskeinen Freiren soveltamisen elementti on empowerment. Avoimeksi kysymykseksi jää, missä määrin Freiren tarkoituksena on ollut lopulta tuottaa nyky-ymmärryksen mukaista empowermentia, minun mielestäni hän antoi siihen eväitä. Hannula päätyykin siihen, että tiedostaminen ei mekaanisesti johda muutokseen, mutta se edistää tietoiseen muutokseen kykenevän ihmisen kasvua. Muutoksen päämäärä Freiren pedagogiikassa esitetäänkin yleisellä tasolla vapautena ihmisyyteen, jota kuvaavat subjektius ja dialogisuus.

\section{Hyvällä omallatunnolla}

voikin kaikille muutosta, ihmisyyteen vapautumista ja tiedostamista sekä myös empowermentia joko valtautumisena tai valtauttamisena tai voimaantumisena aikaansaamista haluaville kasvattajille suositella sekä Hannulan teoksen lukemista että Paulo Freiren kirjallisuuteen tutustumista. Keskeisin tuotanto on englanninkielisenä ja jonkin verran ruotsin- ja saksankielisenä. Espanjankielisenä on otettu uusintapainoksia jopa tänäkin vuonna. Internetistä löytyy kansainvälisiä Freireä käsitteleviä sivuja. Freireen voi siis tutustua, vaikka ei hallitsikaan hänen äidinkieltään portugalia. Kokemuksesta ja Hannulan teoksen vahvistamana voi todeta, että Paulo Freire palkitsee vaivannäön.

Heikki Kemppainen 